\title{
A HEREDITARY COMPONENT IN DEVELOPMENT OF IMMUNE DISTURBANCES IN CHILDREN WITH CHRONIC SINUSITIS
}

\section{S.A. Levytska}

Abstract. The immune disturbances in exudative and hyperplastic forms of chronic sinusitis are accompanied by depression of cell immune response and activation of the humoral one; by a deficit of the factors and mechanisms of nonspecific resistance of organism. A hypothesis of genetic conditionality of the peculiarities of immune reactions and development of the type of chronic inflammation in paranasal sinuses was put forward. The cytosine in position 511 of the promoter zone of IL-1 $\beta$-gene aggravates the suppression of the cell-link of immunity response and a deficit of factors of nonspecific resistance in case of chronic exudative sinusitis while thymine in position 590 of promoter zone of IL-4-zone increases the deficit of factors of non-specific resistance in case of chronic polypous inflammation of paranasal sinuses.

Key words: genetic polymorphism, interleukins $1 \beta$ and 4 , immune status, chronic sinusitis.

Bukovinian State Medical University (Chernivtsi)

Рецензент - проф. І.Й. Сидорчук

Buk. Med. Herald. - 2014. - Vol. 18, № 3 (71). - P. 100-106

Надійшла до редакції 05.05.2014 року

(C) С.А. Левицька, 2014

УДК 618.146-006-08

О.В. Лук'янчук, В.В. Лисенко, М.А. Лисенко

\section{МУЛЬТИМОДАЛЬНЕ ЛІКУВАННЯ ХВОРИХ ІЗ ПРОГРЕСУЮЧИМ РАКОМ ШИЙКИ МАТКИ}

Центр реконструктивної й відновної медицини (Університетська клініка)

Одеського національного медичного університету, м. Одеса

\begin{abstract}
Резюме. Відомо, що однією з особливостей раку шийки матки (РШМ) на пізніх стадіях $є$ місцевий прогресуючий ріст із залученням у пухлинний процес сечових шляхів при відсутності віддалених метастазів. До 68 \% таких хворих на стадії Т3-Т4 мають ті чи інші порушення уродинаміки. При цьому тяжкість стану хворих найчастіше зумовлена саме наростаючою субренальною нирковою недостатністю або лихоманкою, пов'язаною 3 обструктивним пієлонефритом, які часто трактуються як канцерогенна інтоксикація. У зв'язку 3 цим будь-які методи спеціального протипухлинного лікування визнаються малоперспективними навіть для
\end{abstract}

Вступ (актуальність проблеми). На теперішній час, незважаючи на програми ранньої діагностики РШМ, відсоток хворих із пізніми стадіями цієї патології залишається досить високим [1]. Однією з особливостей раку даної локалізації $є$ часте місцеве поширення із залученням у пухлинний процес сечових шляхів при відсутності віддалених метастазів. До 68 \% таких осіб у стадії Т3T4 мають ті чи інші порушення уродинаміки [2]. При цьому тяжкість стану хворих найчастіше зумовлена саме наростаючою субренальною нирковою недостатністю або лихоманкою, пов'язаною $з$ обструктивним пієлонефритом, що часто трактуються як канцерогенна інтоксикація, якою мотивують недоцільність проведення променевої або лікарської протипухлинної терапії [3-6]. У зв'язку з цим пацієнтки, навіть молодого віку, без супутньої соматичної патології змушені одержу- пацієнток без супутньої соматичної патології. Автори провели ретроспективний аналіз лікування 11 пацієнток із місцевопоширеним неметастатичним РШМ, який включав як хірургічне лікування, так і неоад'ювантну поліхіміотерапію (ПХТ). Отримані результати демонструють доцільність мультимодального поетапного лікування таких хворих порівняно 3 паліативним променевим і симптоматичним лікуванням.

Ключові слова: місцевопоширений рак шийки матки, порушення уродинаміки, екзентерація таза, ілеокондуїт.

вати тільки симптоматичну терапію до появи фатальних ускладнень.

Мета дослідження. Розробити алгоритм оптимального лікування хворих на пізніх стадіях неметастатичного раку шийки матки, використовуючи індивідуальний мультимодальний підхід.

Матеріал і методи. Проведено ретроспективний аналіз лікування 11 пацієнток із місцевопоширеним неметастатичним РШМ, які одержували мультимодальне лікування з травня 2009 р. по листопад 2013 р. в Університетській клініці Одеського національного медичного університету. 3 них 7 (63,6 \%) мали порушення уродинаміки, у зв'язку з чим першим етапом була виконана черезшкірна пункційна нефростомія (ЧПНС) під контролем УЗД під місцевою анестезією, що дозволило поліпшити азотовивідну функцію нирок. 
Усі пацієнтки консультовані клінічним онкологом і 8 з 11 (72,7 \%) одержали, у середньому, чотири курси неоад'ювантної платиновмісної ПХТ. Наступним етапом терапії в усіх пацієнток було хірургічне лікування в обсязі екстирпації матки 3 придатками й тазової лімфодисекції 3 різними варіантами реконструкції сечових шляхів: п’ятьом пацієнткам, крім радикальної гістеректомії, виконана резекція сечового міхура, одній хворій виконана резекція сечовода 3 накладенням анастомозу «кінець у кінець», п’ятьом з 11 потрібна була передня екзентерація малого таза з формуванням ілеокондуїту за методом Брікера.

Результати оцінювали за показниками онкоспецифічного виживання впродовж періоду спостереження від 6 до 60 міс. (медіана 31 міс.) та за рівнем смертності до року від прогресії захворювання, які порівнювали з такими для неоперованих хворих. Аналізу зазнав також спектр післяопераційних ускладнень.

Результати дослідження та їх обговорення. Розроблений у клініці алгоритм лікування хворих 3 місцевопоширеним неметастатичним РШМ містив у собі на першому етапі дренування верхніх сечових шляхів методом ЧПНС у 63,6 \% випадків, при цьому ускладнень після даної процедури не відзначалося. Ліжко-день становив одну добу для всіх пацієнток. Обов'язковою умовою був рентгенологічний контроль позиції нефростомічного дренажу. Неоад'ювантна ПХТ проведена в 72,7 \% випадків. Після закінчення неоад’ювантної терапії дві пацієнтки мали регресію пухлинного процесу більше $70 \%$, п'ять - мали регресію пухлини до $50 \%$, в однієї пацієнтки був слабкий терапевтичний ефект - не більше $25 \%$, у зв'язку 3 чим лікування було припинено. Усі пацієнтки оперовані в термін 2-4 тижні після закінчення останнього курсу ПХТ.

Оперативне втручання включало екстирпацію матки 3 придатками, тазову розширену лімфодисекцію та видалення пухлинних інфільтратів

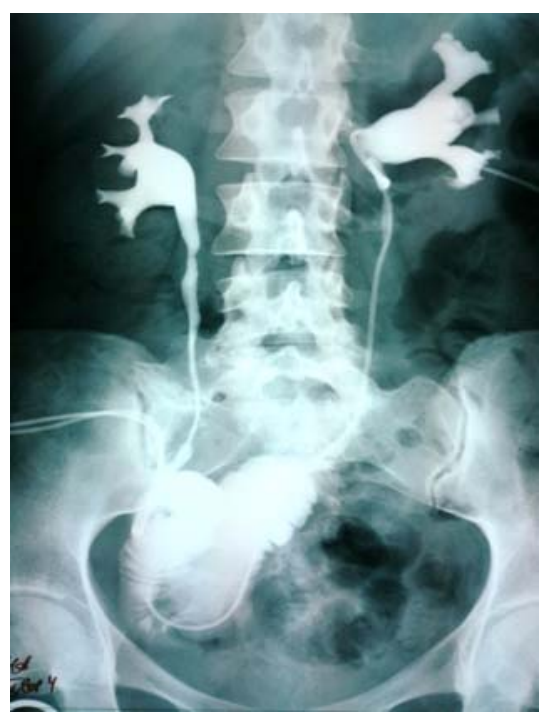

Рис. Видільна урографія пацієнтки Ч. (34 роки) після передньої екзентерації малого таза та формування ілеокондуїту за методом Брікера сечових шляхів, 3 обов'язковим інтраопераційним контролем хірургічного краю резекції по заморожених зрізах. Поширеність пухлини в п'яти 311 (45,5 \%) випадків потребувала цистектомії та резекції дистальних відділів сечоводів; таким чином, обсяг операції можна оцінити як передню екзентерацію малого таза. Оцінюючи післяопераційні ускладнення, слід відзначити тривалу лімфорею, формування лімфокіст малого таза в чотирьох випадках 311 (36,4%), які були вирішені шляхом малоінвазивного втручання - пункції та дренування під контролем УЗД. У двох 311 (18,2 \%) пацієнток мали місце ранові ускладнення, що пов'язано зі зниженням репаративних процесів на тлімножинних курсів ПХТ. У трьох 3 п’яти пацієнток, яким виконана широка резекція сечового міхура, спостерігалося тривале підтікання сечі по уловлювальних дренажах із подальшим зниженням ємності сечового міхура, що суттєво знижувало якість життя хворих. Пізніше ми відмовилися від резекцій сечового міхура при поширеному його ураженні на користь цистектомії з формуванням ілеокондуїту. Дана методика застосована в п'яти 311 хворих і продемонструвала задовільну переносимість, зручність, а головне, - нормалізацію ниркової функції (рис.).

Що ж до онкологічних результатів лікування, то середнє канцерспецифічне виживання для оперованих хворих становила $21 \pm 5$ міс. Смертність до року для цих пацієнток становила 9,1\%. У групі порівняння ці показники становили $9 \pm 5$ міс. та 57,8 \% відповідно. Отримані дані демонстрували високу статистичну вірогідність $(\mathrm{p}<0,01)$.

\section{Висновки}

1. Черезшкірна пункційна нефростомія $\epsilon$ безпечним і надійним методом тимчасового дренування верхніх сечових шляхів при місцевопоширеному раку шийки матки.

2. Попереднє дренування дозволяє не тільки провести неоад'ювантну терапію 3 належним ефектом, але й оцінити справжній функціональний стан нирок, що важливо для планування подальшого лікування.

3. Неоад'ювантна терапія поліпшує результати хірургічного лікування й суттєво не впливає на кількість і структуру післяопераційних ускладнень.

4. При застосуванні неоад’ювантної терапії в пацієнток із місцевопоширеним раком шийки матки недоцільне застосування великих резекцій сечових шляхів. Методом вибору слід вважати передню екзентерацію малого таза 3 формуванням ілеокондуїту.

5. Питання про послідовність етапів лікування повинно вирішуватися індивідуально консиліумом у складі онкогінеколога, уролога, клінічного й радіаційного онкологів із урахуванням саногенетичних можливостей організму хворої.

Перспективи подальших досліджень. У міру накопичення досвіду мініінвазивної хірургії та вдосконалення обладнання буде перспектив- 
ним вивчення можливості використання лапароскопічно асистованого доступу при оперативному лікуванні пацієнток із місцеворозповсюдженим раком шийки матки, що дозволить зменшити морбідність операції та скоротити терміни до початку ад'ювантної терапії.

\section{Лiтература}

1. Бюллетень Национального канцер-регистра Украины. - 2010-2011 гг. - № 13. [Электронный ресурс]. - Режим доступа: www.unci.org.ua.

2. Percutaneous nephrostomy in patients with tumors of advanced stage: treatment dilemmas and impact on clinical course and quality of life / E. Aravantinos, T. Anagnostou, A.D. Karatzas [et al.]// J. Endourol. 2007. - Vol. 21. - P. 1297-1302.
3. Campbell S.C. Pathophysiology of urinary tract obstruction / S.C. Campbell, P.C. Walsh // In: Wein J., ed. Campbell-Walsh Urology $\left[9^{\text {th }}\right.$ ed. $]$ - Saunders, 2007. - Vol. 2. P. 1195-1226.

4. Kreynina J. M. Advanced Cervix Cancer: Optimization of Radio Therapy in Chemoradiotherapetic Treatment / J.M. Kreynina, V.A. Titova // International Journal of Gynecological Cancer. - 2004. - Vol. 14. - P. 191.

5. Chemoradiotherpy for Locally Advanced Cancer of the Cervix - What Are Our Patients' Outcomes? / S. Nair, S.P. Yap, K. Tan [et al.] // International Journal of Gynecological Cancer. - 2004. - Vol. 14. - P. 141.

6. Hydronephrosis as a Prognostic Indicator of Survival in Advanced Cervix Cancer / Tana S. Pradhan, Haiou Duan, Evangelia Katsoulakis [et al.] // International J. of Gynecological Cancer. - 2011. - Vol. 21, № 6. - P. 1091-1096.

\section{МУЛЬТИМОДАЛЬНОЕ ЛЕЧЕНИЕ БОЛЬНЫХ С ПРОГРЕССИРУЮЩИМ РАКОМ ШЕЙКИ МАТКИ}

\section{О.В. Лукьянчук, В.В. Лысенко, М.А. Лысенко}

Резюме. Известно, что одной из особенностей рака шейки матки (РШМ) в поздних стадиях является местный прогрессирующий рост с вовлечением в опухолевый процесс мочевых путей при отсутствии отдаленных метастазов. До 68 \% таких больных в стадии Т3-Т4 имеют те или иные нарушения уродинамики. При этом тяжесть их состояния чаще всего обусловлена именно нарастающей субренальной почечной недостаточностью или лихорадкой, связанной с обструктивным пиелонефритом, которые часто трактуются как канцерогенная интоксикация. В связи с этим любые методы специального противоопухолевого лечения признаются малоперспективными, даже для пациенток без сопутствующей соматической патологии. Авторами проведен ретроспективный анализ лечения 11 пациенток с местнораспространенным неметастатическим РШМ, который включал как хирургическое лечение, так и неоадъювантную полихимиотерапию (ПХТ). Полученные результаты демонстрируют целесообразность мультимодального поэтапного лечения таких больных в сравнении с паллиативным лучевым и симптоматическим лечением.

Ключевые слова: местнораспространенный рак шейки матки, пункционная нефростомия, экзентерация таза, илеокондуит.

\section{MULTIMODAL TREATMENT OF PATIENTS WITH ADVANCED CERVICAL CANCER}

\section{O.V. Lukianchuk, V.V. Lysenko, M.A. Lysenko}

Abstract. Local progressive tumor growth involving the urinary tract with no distant metastases is known to be one of the features of cervical cancer in the advanced stages. Approximately $68 \%$ of patients in stage T3-T4 have various uroevolution disorders. The severity of their condition often is caused by an increasing renal failure or a fever, those are associated with obstructive pyelonephritis and often are interpreted as the carcinogenic intoxication. Therefore, any special antineoplastic therapy methods are considered as unpromising even for patients without concomitant diseases. The authors conducted a retrospective analysis of 11 patients with the treatment of advanced non-metastatic cervical cancer, which included both surgery and neoadjuvant polychemotherapy (PCT). Our results demonstrate the advisability of multimodal phasing treatment of those patients, compared with palliative radiotherapy and symptomatic treatment.

Key words: advanced cervical cancer, puncture nephrostomy, pelvic exenteration, ileokonduit.

Center of reconstructive and restorative medicine National Medical University (University clinic) Odessa

Рецензент - проф. О.М. Юзько
Buk. Med. Herald. - 2014. - Vol. 18, № 3 (71). - P. 106-108

Надійшла до редакції 04.06.2014 року

(c) О.В. Лук’янчук, В.В. Лисенко, М.А. Лисенко, 2014 